\title{
PRAWDZIWY BÓG - PRAWDZIWY CZŁOWIEK WE WSPÓŁCZESNEJ TEOLOGII
}

Współczesna teologia nie zajmuje się specjalnie kwestią sposobu, w jaki doszło do zjednoczenia Bóstwa z Człowieczeństwem w Chrystusie. Obecnie w teologii przedmiotem zainteresowania jest Chrystus jako Człowiek, jako nasz Brat czy po prostu jako Jezus z Nazaretu. Punktem wyjścia dla dzisiejszej teologii bywa zawsze obraz człowieka, jaki znany $\mathrm{mu}$ jest $\mathrm{z}$ własnego doświadczenia, $\mathrm{z}$ własnych życzeń i pragnień. Jeśli jednak podstawą naukowej refleksji nad człowieczeństwem w Chrystusie staje się obraz nas samych, obraz powszedni ziemskiego człowieka, wówczas poszukiwania teologiczne zaczynają natrafiać na pewne trudności. Gdy chodzi o Ojców Kościoła, to łatwo można wskazać na to, że łączyli oni kwestię Jezusa-Człowieka zawsze z kwestią zbawienia człowieka. Nie bali się oni również zajmować się ludzką stroną życia Jezusa. W ten sposób rozwijali swoje rozważania, posługując się możliwie prostym językiem, ilekroć mówili o Jezusie. Sprawie jedności w Chrystusie teologowie scholastyki Baroku poświęcili liczne rozprawy. Starali się oni w rozważaniach metafizycznych ustalić różnicę między naturą i osobą, która by dozwoliła ujrzeć w Jezusie Chrystusie pełnego człowieka, który jest w osobie Syna Bożego. Te rozważania nowsza teologia odsuwa na bok, lecz samo zagadnienie nasuwa się ciągle i ponownie. W pierwszym rozdziale zadajemy pytanie o pojęcie prawdziwego człowieczeństwa w nowszej chrystologii. W drugim wskazujemy na próby rozwiązania zagadnienia przez Ojców Kościoła. W zakończeniu będziemy się starali znaleźć granice problemu i będziemy poszukiwać dróg prowadzących do jego rozwiązania.

ZAIGADINIENIE PRAWDZIWEGO CZEOWIEKA W NOWSZEJ CHRYSTOLOGII

Nowsza chrystologia pyta o człowieka w Jezusie Chrystusie. Szuka ona postaci Jezusa z Nazaretu i chce go odnaleźć jako brata ludzi. Te poszukiwania przybierają rozmaitą postać, w zależności od pochodzenia i zainteresowań teologów.

W Panu naszym Jezusie Chrystusie Karol Adam (1876-1966) starał 
się ująć i przedstawić „życie ludzkie w jego najszlachetniejszej, najpiękniejszej postaci" ". Zapobiegliwie i starannie zbierał on z Pisma świętego wypowiedzi o wielkości i sile promieniowania ludzkiej postaci Jezusa w jej oddziaływaniu na ludzi, którzy Go spotykali ${ }^{2}$. Przedstawiając szlachetne człowieczeństwo Jezusa chce Adam doprowadzić do wiary w Jezusa jako Chrystusa i ukazać Go jako tego pośrednika, który w swoim ludzkim bycie zaprowadza ludzi do Boga. Chodzi mu o tego człowieka Jezusa, „który przez osobisty związek swej człowieczej natury z Słowem Bożym i przez moc tego związku, przez swą śmierć i zmartwychwstanie, stał się naszym pośrednikiem, naszym Odkupicielem i naszym Zbawieniem" ". Ponieważ utrafił on w ton swoich czasów, udało mu się w bardzo wielu swoich słuchaczach i niezliczonych czytelnikach swych książek wzbudzić i pogłębić wiarę i miłość do Jezusa Chrystusa, pośrednika między Bogiem a ludźmi. Przy całej oględności, z jaką powołuje się na Pismo, rysuje on obraz Jezusa Chrystusa, który odpowiada obrazowi szlachetnego człowieka w jego pojęciu i w pojęciu jego czasów ${ }^{4}$. Obraz, który przedstawia, wykazuje nie tylko rysy wzięte $\mathrm{z}$ Pisma, lecz również rysy jego pojęcia o szlachetnym i prawdziwym człowieku.

Grillmeier widzi właściwy przyczynek swoich czasów „ku pogłębieniu i kontynuowaniu przekazanej chrystologii” w ,pytaniu o ludzką świadomość Jezusa Chrystusa" ${ }^{5}$. Potrafi on wskazać, że w tym zagadnieniu walczą teologowie o zrozumienie prawdziwego człowieczego bytu Jezusa Chrystusa.

Paul Galtier przyjmuje istnienie człowieczego ,,ja” w Chrystusie, różniącego się od osobowości boskiej. Świadomość jest wyrazem natury duchowej, a nie osoby. W działaniu tej świadomości doświadcza siebie człowiek jako istota duchowa ${ }^{\circ}$. Galtier przyjmuje świadomość swojego „ja”,

1 Karl A d a m, Jesus Christus und der Geist unserer Zeit, Augsiburg 1935, s. 25. W. K a s p e r, Karl Adam: ThQ 156 (1976), s. 241-259 z biblliografią; F. H o f m a n n, Theologie aus dem Geist der Tübinger Schule: ThQ 146 (1966), s. 262-284.

2 Por. Karl A d aim, Jesus Christus, Düsiseldorf 1919, is. 87 in!.

3 Tamże, s. $13 / 14$.

4 „Er stand somit auf der Höhe Seines Lebens und Seiner Kraft, als Er Seine Verkündigung begann” tamże, s. 89. „Seline leibliche Gestalt muß überaus einnehmen und gewinnend ja faszinierend geweisen sein" tamże, s. 911 (z odesłaniem do 乇k 2, 5i2). "So muß etwals Strahlendies, Leuchtendes von Seiner Erscheiniung ausgegangen sein" tamże, s. 91: Chodzi o jalsną świadomość celu Jego myślii, o zdecydowaną, jasną wolę (s. 96). ,Sein Wesen und Leben ist ganz gar Einheit, Gelschlossenheit, Herrlichkeit, ursprüngliche Klarheit und Wahrheit. Es trug derart das Merkmal des Echten, des Wahren, des Aufrechtien und Starken, daß sich selbst seine Feinde diesem Eindruck nicht entziehen konnten" s. 98 z odesłaniem do Mk $110,14$. ,Jesus ist ein durchaus heroilscher, heldischer Charakter, das menschgewordene Heldentum" tamże, s. 98. Miłość do ubogich jest dla Niego: ,etwas Urtümliches ein Urgefühl Seines Herzens, herausquellend aus jenem starken Drang des Mit Leiden's mit den Leidenden" tamże, s. 125.

5 A. Grillme i e r, Mit ihm und in ihm. Christologische Forschungen und Perspektiven, Freiburg 1975, s. 702.

- Por. również tamże, s. 703 nn. 
które nie musi być osobą. W ten sposób może on odróżnić świadomość człowieczeństwa Chrystusa od boskiego „Ja” w Chrystusie. Między nimi nie ma przejścia. Złączone one są przez bezpośrednie oglądanie Boga, w którym człowieczeństwo Jezusa widzi się zjednoczone ze Słowem (Logos) i doświadcza siebie jako związane w swoim ,ja” z Osobą Słowa. ,Życie wewnętrzne Jezusa określone jest z siebie w wolności i zwartości" 7. W Jezusie Chrystusie poszukuje się najbardziej możliwie samodzielnej i zwartej w sobie świadomości ludzkiej. Ta samodzielna i zwarta świadomość tworzy człowieka.

Karol Rahner wychodzi z tego, że duchowy byt wyraża siebie jako byt-u-siebie. Żąda on dla człowieczeństwa Chrystusa najwyższego stopnia duchowego bytu-u-siebie. Z tego powodu staje on przed trudnością wyjaśnienia, jak w Chrystusie natura człowiecza może być u siebie, a jednak w tym byciu-u-siebie doświadczyć bytowego zjednoczenia z Logosem $^{8}$. Rahner stara się tę świadomość synostwa Bożego wytłumaczyć przez podstawowe samopoczucie człowieka, jego duchowość i jego swobodnie czynne samozrozumienie. Bezpośrednie oglądanie Boga wyjaśnia jako bezprzedmiotową świadomość boskości i rozumie w oparciu o świadomość Jezusa historycznego, która dopuszcza pytania, wątpliwości i naukę.

Schoonenberg jest zdania, że sformułowanie chalcedońskie przez zmianę znaczenia swoich pojęć jest obecnie niezrozumiałe. Przy prostym przekazie tego sformułowania człowiek Jezus Chrystus znajduje się „,w niebezpieczeństwie wypróżnienia na korzyść boskiej osoby"9. Rozumie on Jezusa Chrystusa jako osobę i jako ludzką osobę. Człowiek jest pojmowany w jego otwartości na Boga. Dlatego Bóg może sprawiać swoją łaskę w ludziach i przez ludzi, bez zadawania człowiekowi gwałtu. Syn Boży może więc działać w ludzkiej osobie Jezusa i przez ludzką osobę Jezusa.

Zwrot w chrystologii biblijnej zapoczątkował Ernst Käsemann. W przeciwieństwie do swego nauczyciela Bultmanna, którego interesował wyłącznie Chrystus przepowiadany, wypracował on kryteria, które miały umożliwić historyczny dostęp do Jezusa. Wywołało to w badaniach egzegetycznych pytania o Jezusa ziemskiego, o Jego nauczanie, o Jego postępowanie i Jego życie ${ }^{10}$. Masa książek o Jezusie z Nazaretu, Jego

7 Tamże, s. 704.

8 Por. tamże, s. $710 \mathrm{nn}$. i K. R a h ner, Probleme der Christologie von heute: Schriften I, S. 169-222; Dogmatische Erwägungen über das Wissen und Selbstbewußtsein Christi: Schriften V, s. 222-245.

9 P. S choone n berg, Ein Gott der Menschen, Zürich-Einsiedeln-Köln 1969, s. 193. Por. A. Schils on, W. Kas per, Christologie im Präsens, Freiburg 1974, s. $115-122$.

10 Por. E. Kös eman, Das Problem des historischen Jesu, ZThK 51 (1954), s. 125-153; Exegetische Versuche und Besinnungen 1, Göttingen 1964, s. 187-214. 
nauce, Jego postaci i Jego historii pojawia się na rynku ksiągarskim ${ }^{11}$. $\mathrm{W}$ tej literaturze doszukiwano się $\mathrm{w}$ Jezusie przede wszystkim wzorowego człowieka. Bardzo liczni autorzy wyjmowali obraz z ram kościelnych, pragnąc Go widzieć w Jego człowieczeństwie, w Jego nauczaniu, w Jego postępowaniu. Ten tak przedstawiony Jezus-człowiek miał wzywać do pójścia za Nim, przekonywać, zapraszać do życia w służbie bliźnego. Jezusa przedstawiano jako człowieka, który jest wolny od przymusów społeczeństwa i prowadzi ludzi do wyzwolonego bytowania. Również $\mathrm{w}$ poważniejszych poczynaniach tego rodzaju pojawia się ciągle na nowo usiłowanie zastąpienia przemalowań obrazu Jezusa poczynionych przepowiadaniem pierwotnej gminy, tradycją w Kościele i za pośrednictwem Kościoła, przez postać Jezusa uzyskaną na podstawie pracy krytyczno-historycznej. Powszechnie ważne drogi ludzkiego poznania mają przedstawić powszechnie uznawany obraz Jezusa. Poszukuje się człowieka Jezusa w Jego czasach i w Jego otoczeniu. Znajduje się zwykle obraz Jezusa-człowieka, odpowiadający pojęciu autora o człowieku i bycie człowieka. Poszukuje się Jezusa człowieka; znajduje się pojęcie człowieka, które już uprzednio istnieje. Wysiłek naukowej uczoności daje ten obraz człowieka, z którego zawsze już wychodzono.

Idąc za ciągiem tego ruchu, również Küng poszukuje historycznej chrystologii odpowiadającej dzisiejszemu człowiekowi, wychodząc od konkretnego, historycznego Jezusa. Wychodząc ,od rzeczywistego człowieka Jezusa, Jego historycznego orędzia i historycznej postaci, Jego życia i losów, Jego historycznej rzeczywistości i historycznej działalności" pyta się on o "stosunek tego człowieka-Jezusa do Boga, o Jego jedność z Ojcem" ${ }^{12}$. W dążności do poważnego traktowania ludzkiego bytu Jezusa wykłada na nowo przekazane wypowiedzi. Wypowiedzi o Synu Bożym przekłada na wypowiedzi o rzeczniku Boga. Przekazane wyznanie o Jezusie Chrystusie jako Synu Bożym rozumie jako wyznanie o Bogu, którego roszczenia przychodzą do głosu w Jezusie Chrystusie, w którym "dla wierzących przyjazny ludziom Bóg sam był bardzo blisko" ${ }^{13}$. W tym roszczeniu i bliskości Boga chodzi o sprawę człowieka, o człowieka. Bóg pragnie dobra człowieka. Chce on „życia, radości, wolności, pokoju, zbawienia, ostatniego wielkiego szczęścia człowieka: jednostki i ogółu” ${ }^{14}$. Na czym polega to wielkie szczęście człowieka - nie mówi. O ile je opisuje, wymienia wewnątrzoświatowe sposoby zachowania. „Być chrześcijani-

11 Por. J. Rollof, Auf der Suche nach einem neuen Jesubild: ThL 98, (1973), s. 561-572. Najważniejisza literatura w: H. L e r o y, Jesus, Darmsitadt 1978, s. 143154; W. G. K ü m m e 1, Jesusforschung: ThR 411 (1976), s. 225-363; 43 (1978), s. 245$265 ; 45$ (1980), s. $330-337 ; 47$ (1982), s. $136-1165,348-383$.

i2 $\mathrm{H}$. K ü n g, Chritsein, München-Züriich 1974, s. 125.

18 Tamże, s. 440.

14 Tamże, s. 2411 . 
nem" rozpatruje z pozycji bytu człowieczego, a bycie człowiekiem z pozycji chrześcijańskiego bycia. Chrześcijańskie bycie potrafi zintegrować i przezwyciężyć „,również nieprawdziwe, niedobre, niepiękne i nieludzkie" ${ }^{15}$. Może znieść cierpienie, winę, śmierć i bezsens, ponieważ wie, że ma oparcie w Bogu. Ale w gruncie rzeczy nic się człowiekowi tym nie obiecuje. W takim pokoju z Bogiem pozostaje on w końcu sam ze sobą. Można się więc zgodzić z Ratzingerem: „w walce o człowieka, na którą jesteśmy wydani, nie jest to odpowiedź dostateczna" ${ }^{16}$. Zwrotnice ku tym odpowiedziom zostały nastawione jednak w chrystologii przez Küngowe 'Być chrześcijaninem'.

Schillebeeckx pragnie zrozumieć jedność w Chrystusie od strony zbawienia, które w Jezusie z Nazaretu ukrzyżowanym i zmartwychwstałym zostało podarowane przez Boga ostatecznie i nieprzekraczalnie $\mathrm{w}$ historii Jezusa z Nazaretu. „Bóg odkupia, ale w i przez człowieka Jezusa, Jego nauczanie, Jego życie i śmierć" ${ }^{17}$. Chodzi Mu o życie, cierpienie i umieranie Jezusa, w którym samoofiarowanie się Boga staje się rzeczywistością historyczną $w$ wyobcowaniu ludzkiego życia i śmierci. Pragnie on obstawać przy ludzko-osobowym sposobie bycia Jezusa Chrystusa, ,aby uczynić zrozumiałym głębokość odkupiającego samopoświęcenia Boga, a jednak nie umieszczać w Bogu cierpienia, śmierci i wyobcowania, lecz pozostawić je tam, gdzie rzeczywiście należą, w ziemskiej rzeczywistości ludzkiej egzystencji” ${ }^{18}$. Schillebeeckx rozważa, co oznacza „byt człowieczy" i jest zdania, że nasze pojęcie człowieczeństwa nie może być miarą, według której moglibyśmy oceniać Jezusa. Raczej Jego człowieczeństwo musi stanowić miarę, według której powinniśmy osądzać nas samych. W Jezusie widzi on objawienie tego, co może oznaczać bycie człowiekiem ${ }^{19}$. Byt człowieczy stara się Schillebeeckx zrozumieć od strony historii Jezusa Chrystusa, ale to jest historia ludzkiej osoby Jezusa; Boga nie należy $\mathrm{w}$ to mieszać. Oczywiście, wyraża się on jednak bardzo nieokreślenie ${ }^{20}$. Nie wypowiada się jasno, czy tu cierpi ludzki podmiot Jezus, czy Syn Boży. Człowieka rozumie i określa przez historię i w tejże historii. Dla tego historycznego rozważania zdaje się Schillebeeckx poszukiwać nowej wykładni starej formuły zjednoczeniowej, za pomocą której można wyraźniej odróżnić Syna Bożego od Jezusa człowieka.

W podobny sposób stara się Wiederkehr o takie zrozumienie jedności

15 Tiamże, s. 594 .

${ }^{16} \mathrm{~J}$. R a t z inger, Christ sein - plausibel gemacht: ThiRw 71 (1975), s. 364.

17 E. S chille beeck x, Jesus. Die Geschichte von einem Lebenden, Freiburg 1975 , s. 591.

18 Tamże.

19 Por. tamże, s. $428 \mathrm{n}$.

20 ,Und die Leiden, Tod und Entfremdung nicht in Gott zu verlegen, sondern sie dort zu lasisen, wo sie in Wirklichkeit hingehören: In die weltliche Wirklichkeit men'schlichen Daseins". Tamże, s. 591. 
Jezusa Chrystusa, które by dopuszczało historię świadomości synostwa Jezusa, aż do Jego pełnego objawienia $w$ zdarzeniu Wielkanocnym ${ }^{21}$. Wiederkehr usiłuje tę historię Jezusa przedstawić od strony ram stosunku Boga do świata i stosunku świata do Boga. Historię Jezusa pojmuje jako eschatologiczne lub skończone wykonanie tego stosunku Boga i świata. Na podstawie życia i historii Jezusa Chrystusa wyjętych z Pisma pokazuje bytowanie Jezusa Chrystusa jako Boga-człowieka a Jego działalność jako działalność bosko-ludzką. Nie traci z pola widzenia tego, że druga Osoba Boska, Syn Boży, stała się człowiekiem. Istnienie i historia Boga-człowieka osiągają swą jedność w ukierunkowaniu Syna na Ojca.

Walter Kasper podejmuje w zagadnieniu jedności Boga i człowieka w Chrystusie rozumienie osoby, które wychodzi z dwóch podstawowych ludzkich doświadczeń. Człowiek doświadcza siebie jako „niezastąpione i niewymienne ja" ${ }^{22}$. Z drugiej strony nie jest człowiek istotą w sobie zamkniętą, lecz określoną przez rzeczywistość i „otwartą na wszelką rzeczywistość" 23. Osobowość realizuje się w związkach, w odgraniczaniu się i otwieraniu się na otoczenie. To obejmują stosunki człowieka z Bogiem. „Jednorazowość jak też otwartość osoby domagają się podstawy, dlatego osoba jest nie tylko odniesieniem, lecz też udziałem w istocie Boga. Osobę ludzką można więc zdefiniować ostatecznie wychodząc jedynie od Boga i dochodząc do Niego; Bóg sam należy do definicji ludzkiej osoby" ${ }^{24}$. Kasper widzi istotę osoby i tego co osobowe w pośrednictwie. Przez jedność w postaci Syna Bożego osiagga „osobowość człowiecza swoje konieczne, jednorazowe i niewyprowadzalne spełnienie" ${ }^{25}$. Kasper otwiera to zrozumienie w stronę Trójcy Swiętej. Jezus Chrystus jest historyczną wykładnią trójosobowości. Z tego punktu widzenia może on rozumieć pośrednictwo Boga i człowieka w Chrystusie ,,jedynie jako wydarzenie w Duchu Swiętym" ${ }^{26}$.

Hünermann rozumie człowieka jako ,bycie-przy-innym w swoim własnym istnieniu" ${ }^{27}$. W tym własnym istnieniu człowiek się zastaje. Tej godności nie można go pozbawić. Człowiek odzwierciedla „w swym własnym istnieniu godność i wolność absolutnej, boskiej istoty w określony

21 Por. Mysterium Salutis. Grundriß heilsgeschichtlicher Dogmatik. Tom 3/1, s. 5ịlo nn. „Wenn Ositern diese rückwirkende Bedeutung und Erhellung ausübt, dann kann dies nicht heißen, daß vom Ende her die echte Geschichtlichlkeit diese's Weges des Sohnes aufgerollt und uneigentlich wird: Jesus ist vielmehr sio S.ohn Gottes, daß er Sohn Gottes wird". Tamże, s. 528.

22 W. K a s per, Jesus der Christus, Mainz 1974, s. 290.

${ }_{23}$ Tamże, S. 291 .

24 Tamże, s. 291/2912.

25 Tamże, s. 295.

26 Tamże, s. 296.

27 P. Hünermann, Gottes Sohn in der Zeit. Entwurf eines Begriffs. w: Grundfragen der Christologie heute poid red. L. S cheffczyk, Freiburg 1975, S. 118 . 
sposób" ${ }^{28}$. Z tego wynika: człowiek jest tym bardziej doskonałym człowiekiem, im mocniej rozwinęła się jedność z Bogiem" ${ }^{29}$. W stanie winy może się człowiek wyrzec tej partycypacji, jednak mimo oddalenia od Boga pozostaje on z Nim związany pochodzeniem, które mu ten udział dało. Wychodząc z tej myśli, odważa się Hünermann na przybliżone wyobrażenie o tajemniczym pojednaniu z Bogiem. Natura ludzka, która w swoim byciu-przy-innym nigdy nie może się stać doskonałą samą ze siebie, znajduje zjednoczona z naturą Boską swą doskonałość jako ludzka. Ludzki samostan, który nigdy nie może osiągnąć doskonałości sam ze siebie, zyskuje siebie w samostanie Bożym i staje się doskonałym pozostając sam w sobie. Od Jana z Damaszku i jego pojęcia, o perychorezie, wzajemnym przenikaniu się Boskiego i człowieczego, wykłada się tę Jedność Chrystusową jako proces, jako żywe, przebiegające w historii zdarzenie ${ }^{30}$. Te myśli pozwalają Hünermannowi na interpretację śmierci i zmartwychwstania Jezusa Chrystusa jako doskonałego samoobjawienia się Boga i zrozumienie oddania się wywyższonego swemu Kościołowi z pozycji unii hypostatycznej ${ }^{31}$. Te pojęcia przedstawione w sposób wysoce abstrakcyjny powinny być wyraźniej odgraniczone i przekazane wespół z historią życia Jezusa taką, jak ją poświadcza Pismo. Hünermann uznaje, że wniesione przez niego rozumienie człowieka zostało umożliwione przez Chrystusa i przez teologiczną myśl o Chrystusie.

Hans Urs von Balthasar stara się zrozumieć Jedność w Jezusie Chrystusie od strony Jego posłanictwa. Przez posłannictwo jest Jezus Chrystus skierowany na posyłającego, na Ojca. Z drugiej strony chce on wykonać to posłannictwo siłami ludzkimi. To posłannictwo spełnia On krok za krokiem, spełniając wolę swego Ojca ${ }^{32}$. Ponieważ Chrystus jest wolny i wykonanie posłannictwa nie jest $z$ góry po prostu zadane, można zrozumieć kuszenie Jezusa, Jego modlitwy, Jego mowy o wierze w Jezusa, niewiedzę, naukę i wolność. Oprócz tego udaje się pokazać wykonanie tego posłannictwa w historii i historyczności. Wreszcie posługuje się Balthasar w celu wyjaśnienia Jedności w Chrystusie także chrystologiczną interpretacja „Analogia entis”. Mimo, że nie pisze o psychologii Jezusa, wygłasza jednak wiele bardzo subtelnych rozważań o świadomości posłannictwa i samoświadomości Jezusa. Wyjaśnienia tajemnicy, jak Syn Boży jako człowiek żyje, cierpi i umiera, nie jest w stanie w końcu podać również Hans Urs von Balthasar. Jednak udaje mu się, wyraźniej niż innym, wyjaśnić Jedność Syna i człowieka w posłannictwie.

28 Tamże, s. 119.

29 Tamże.

30 Por. tamże.

31 Por. tamże, s. 134 n.

32 Por. Hans Urs von Balthasar, Theodramatik 2/2, Einsiedeln 19r8, ร. $149 \mathrm{nn}$. 
Wymienieni ostatnio teolodzy przejmują bardzo świadomie wypowiedzi Soborów i starania o ich wykładnię i zrozumienie. Podczas gdy inni teolodzy usiłują uwolnić Boga od wszystkiego co ludzkie, ze względu na człowieka, oni są gotowi pozostawić Bogu doświadczenie tego co ludzkie w Jego Synu. W Jezusie Chrystusie przybył Syn Boży, oddał się na krzyżu za ludzi. Ponieważ przekładają oni swoje poznanie z Tradycji na zrozumienie współczesnego człowieka, również oni - oczywiście o wiele bardziej samokrytycznie i w większej wierności wobec Tradycji - wnoszą pewien obraz człowieka do zrozumienia Jezusa Chrystusa. W rzeczy samej, widzą oni byt ludzki jako dany i spełniony przez Boga. Bóg daje wolność stworzonemu przez siebie człowiekowi, również temu, który jest w Synu Bożym złączony z Jego naturą. Jako najściślej złączony z Bogiem może być Jezus Chrystus prawdziwym człowiekiem.

\section{JEZUS CHRYISTUS — PRAIWDZIWY CZEOWIEK W TEOLOGII OJCOW}

Zagadnieniem ludzkiego bytu Jezusa Chrystusa zajmowali się już Ojcowie w sporach chrystologicznych starożytnego Kościoła. Myśl chrześcijańska poszukiwała zawsze człowieka w Jezusie Chrystusie. We wszystkich sformułowaniach wyznania wiary mówią o Synu Bożym, który stał się człowiekiem, o Jego śmierci i zmartwychwstaniu. Tradycji wiary i myśleniu w wierze nasuwa się ciągle na nowo pytanie, jak ten prawdziwy człowiek i Bóg prawdziwy może być Jednością. Począwszy od Ireneusza, Ojcowie widzą Wcielenie Chrystusa od strony Odkupienia. Ireneusz widzi w Słowie Bożym, w Jezusie Chrystusie, naszego Pana, który „z powodu swej nieskończonej miłości stał się tym, czym myśmy się stali, aby nas uczynić w sposób doskonały tym, czym jest On" ss. Słowo, które stało się ciałem, pokazuje człowieka jako prawdziwy obraz Boga. Ponieważ Słowo, Syn, stało się człowiekiem, dlatego ustanowiło ,,podobieństwo na pewno, kiedy uczyniło człowieka podobnym do niewidzialnego Ojca przez widzialne Słowo" ${ }^{\text {44. }}$

Orygenes przejmuje ten pogląd. W swojej rozmowie z Heraklidesem, powiada: „Ponieważ Zbawiciel i nasz Pan chciał człowieka tak uratować, jak go chciał uratować, chciał On uratować ciało i chciał podobnie uratować duszę i chciał też resztę człowieka uratować, ducha. Gdyż nie byłby uratowany cały człowiek, gdyby był nie przyjął całego człowieka" ${ }^{35}$.

33 Ireneusz, Adversus haereses 5, praef. - W. H a rve y 2, s. 314. „Damals aber zeigte sich dieses Wort, als das Wort Gottes Mensch geworden ist, indem es slich den Mienschen und den Mensichen sich anglich, damit der Mensich durch seine Ahnlichkeit mit dem Sohn kostbar werde". Tamże, s. 5, 16, 2 - Harvey 2, S. 368 .

${ }^{34}$ Tamże.

35 Orygenes, Dialog $z$ Heraklidesem 7, 1-6: SC 67, 70, 13-19. 
W oparciu o ten postulat, że tylko to jest zbawione, co zostało przyjęte przez Syna Bożego, Orygenes przenosi pojęcie człowieka i preegzystencji dusz na Chrystusa. Zdumiewa go cud, że odwieczne Słowo „obecne było w wąskich granicach tego człowieka, który zjawił się w Judei" ${ }^{80}$. Logos wstąpił we wspólnotę ludzkiej natury i przyjął cielesność człowieka, którą trapią żądze przeciw duchowi. W nim rozpoczyna się splot natury boskiej z ludzką. Przechodzi z Jezusa na wszystkich, w których z wiarą rozpoczyna się życie ${ }^{37}$. Jezus może o sobie mówić jako o człowieku, ale również jako o naturze Boga ${ }^{38}$. Sposób jedności w Chrystusie pozostaje w ukryciu ze względu na siłę porządku zbawienia. Żaden człowiek nie może wskazać tego sposobu zjednoczenia ${ }^{39}$.

Myśli Orygenesa działają nadal. Również Atanazy widzi Wcielenie od strony Odkupienia. Syn Boży stał się człowiekiem dla ludzi. Wyraźniej formułuje to Grzegorz z Nazjanzu: Bóg stał się człowiekiem dla ludzi, abym ,ja stał się tak samo Bogiem, jak Bóg stał się człowiekiem" "40. Grzegorz z Nazjanzu widzi prawdziwe człowieczeństwo Chrystusa od strony tezy: „co nie zostało przyjęte, nie jest zbawione; co się z Bogiem zjednoczyło, to będzie też uratowane" "1. Cyryl z Aleksandrii trzyma się prawdziwego człowieczeństwa Chrystusa. Zaprzeczać, że Jezus Chrystus się uczył i modlił znaczyłoby pozbawiać porządek Zbawienia siły ${ }^{42}$. Leoncjusz z Bizancjum zauważa: „Większość Ojców przyznała, że Chrystus pewnych rzeczy nie wiedział. Ponieważ jest On tej samej istoty co my, i ponieważ my sami nie wiemy pewnych rzeczy, jest jasnym, że Chrystus również był poddany niewiedzy. Mówi też o Nim Pismo: «przybierał na wieku i mądrości» (Łk 2, 52), tzn. jednak, że uczył się czegoś, czego przedtem nie wiedział" ${ }^{43}$.

Jan z Damaszku pragnie przedstawić jedność w Chrystusie w mowie pełnej prostoty. „Cały jest teraz doskonałym Bogiem, całość jednak nie jest Bogiem (bo nie tylko Bogiem, lecz też człowiekiem), i cały jest doskonałym człowiekiem, całość jednak nie jest człowiekiem (ponie-

36 Orygenes, Peri archon 2, 6, 2. Görgemanns, Karpp, Darmstadt 1.976 , s. 358,29 n.

37 Por. Or y e n es, Komentarz do Ps. 118, 151: von Balthas ar, Origenes, Geist und Feuer $\mathrm{Nr} 276$. Na temat chrystologii Orygenesa por. A. Grill meier, Jesus der Christus im Glauben der Kirche 1. Freiburg 1979, s. 266-280; P. S mu lders, Dogmengeschichtliche und lehramtliche Entfaltung der Christologie: MySal 3/1. Einsiedeln 1970, s. $418-422$.

38 Por. Orygenes. Komentarz do Ewangelii św. Jana 19, 2: P r e u sic he n, 29i3.

${ }^{39} \mathrm{Gr} i 11 \mathrm{meier}$, Jesus der Christus, s. 278. Por. Orygenes, Komentarz do Ewangelii sw. Jana 1, 23: P r e u s che n GCS, Orygenes Werke IV, 498, 20-27.

40 Grzegorz z Nazjanzu, Oratio 29, 19: PG 36, 100A. Por. Gri11meier, Jesus, s. 539 .

${ }^{41}$ Grzegorz z Nazjanzu, List 101 ad. Cledon.: PG 37, 181C - 1841A.

${ }^{42}$ Cyryl. Dial. de Trin. 6: PIG 75, 106 A: SC 246, $120 \mathrm{f}$.

43 Leoncjusz z Bizancjum, De sectis: PG 86, 1264 A/B. Por. L. B o u y e r, Das Wort ist der Sohn, Einsiedeln 1976, s. 4112. 
waż nie tylko człowiekiem, lecz także Bogiem). „Całość” oznacza tu naturę, "Cały" hypostazę, tak jak "Inne” naturę i "Inny” hypostazę" ${ }^{44}$. Syn Boży przyjął wszystko, ciało, duchową i rozumną duszę i własności, które czynią człowieka człowiekiem. „Cały” przyjął całego człowieka, aby „Całości” podarować zbawienie ${ }^{45}$. Przyjął On nawet „wszystkie naturalne i nienaganne afekty ludzkie" ${ }^{46}$. Pod tymi naturalnymi i nienagannymi afektami rozumie on te, które są od nas niezależne, lecz weszły w ludzkie życie na zasadzie wyroku. Wylicza: głód, pragnienie, zmęczenie, trud, łzy, przemijanie, lęk przed śmiercią, strach, obawę - wszystko to, czym natura obarczyła człowieka ${ }^{47}$. Także Jan z Damaszku dostrzega, że przyjęta natura jest niewiedzącą i służącą, ale z powodu jej nierozłączalnej jedności - tak uważa - dusza Chrystusa obdarzona jest znajomością przyszłości. W przeciwieństwie do Leoncjusza i Cyryla odrzuca on postęp w poznaniu u Jezusa ${ }^{48}$.

U Ojców okazuje się, że sięgnięcie wstecz po prosty język posuwa naprzód ich poznanie i tworzenie pojęć. W ten sposób Grzegorz z Nazjanzu zauważa, że w Bogu jest inny i inny, a nie ,inne” i ,inne”. W przedstawianiu Marii jako Rodzicielki Boga, ostrzega on, że nie można wprowadzać dwóch synów, jednego z Boga Ojca, a drugiego z Matki. Trzeba widzieć razem inne $\mathrm{i}$ inne, z których jest Zbawiciel, a nie innego $\mathrm{i}$ innego. „Ale ja mówię inne i inne, w Trójcy zaś jest odwrotnie. Tam jest Inny i Inny, aby nie mieszać hypostaz, a nie inne i inne. Jednością są mianowicie trzej $\mathrm{i}$ to $\mathrm{w}$ Bóstwie" ${ }^{49}$. Przy pomocy tego konkretnego języka dochodzą Kapadocczycy do rozróżniania między istotą i hypostazą, naturą i osobą.

Jan z Damaszku dochodzi przez swoją mowę o Całym i Całości do przekonania, że Słowo nie przyjmuje abstrakcyjnej człowieczej natury, lecz jest konkretną jednostką, która ma swoją hypostazę w Synu ${ }^{50}$. Uznaje, że „hypostaza Boskiego Słowa stała się hypostazą dla ciała” ${ }^{1}$. Hypostaza Słowa, które stało się ciałem, staje się dla człowieczeństwa Jezusa źródłem właściwego ludzkiego istnienia ${ }^{52}$. Tym sposobem jest on $\mathrm{w}$ stanie ując pojęciowo pewne rozumienie u Atanazego. Logos jest rzeczy-

44 Jan z Damaszku, Expositio fidei 51: K otter, Berlin 1973, 126, 52-56.

45 Pior. Jan z Damaszku, Expositio fidei 50; 3, 6: K o t ti e r 121, 32-38.

${ }_{46}$ Tamże, 64; 3, 20: K otte r 162, 1: BKV 174.

47 Por. tamże.

48 Por. tamże. $64-66$; 3, 20-22: K o t t e r, 162-165.

49 Grzegorz z Nazjanzu, List 1011 ad. Cledon 1: PG 37, 180 A/B. Por. G ril1meie r, Jesus der Christus, s. $538 \mathrm{nn}$.

50 Por. J. M e yendorff, Le Christ dans la theologie byzantine, Paris 1969, s. $207 \mathrm{nn}$. "Und wir bekennen 'eine fleischgewordene Natur des Gott Logos'. Da wir 'fleischigew ordene' sagen, bezeichnen wir die WWesenheit dels Fleischies gemäß Cyrill. Und fleischgeworiden ist der Logos". Expositio fidei 51: K o t te r 125, 45-47.

51 Jan z Damaisizku, Expositio fidei 5i5; 3, 11: Kotte r 131, 14.

52 Por. Expositio 50; 3, 6: K ot te r 121, 32-38. 
wiście poruszającą zasadą w Chrystusie, któremu należy przypisać decydujące duchowo moralne akty ${ }^{58}$. Logos i człowiek nie stoją na równej płaszczyźnie. Nie są oni związani w nadrzędnym trzecim. To Logos dźwiga człowieczeństwo Chrystusa. To nie jest człowiek, który dźwiga Boga. To Bóg stał się w Logosie człowiekiem: ciało niesie w Logosie Bóg ${ }^{54}$.

\section{Człowiek od strony bycia osoba.}

$\mathrm{Na}$ Zachodzie oddziaływało przede wszystkim doświadczenie Boecjusza ${ }^{55}$. Szkoły scholastyki i scholastyki Baroku pragną określić osobę w odróżnieniu od natury. Wszystkie te próby rozumieją osobę jako coś dodatkowego do natury człowieczej, jako bliższe określenie natury człowieka. Jak Ojcowie, rozumieją oni człowieka z pozycji człowieka. To rozumienie uzyskane na człowieku przenoszą na Chrystusa. Pojawia się wtedy trudność wyjaśnienia, jak może się mieścić człowiecza natura Chrystusa w osobie Syna Bożego.

\section{Odkupienie człowieka}

Podczas gdy Ojcowie rozpatrywali zagadnienie bycia człowiekiem lub Wcielenia Syna Bożego zawsze w powiązaniu z Odkupieniem, to w teologii średniowiecznej, a przede wszystkim w jej wykładni nowożytnej nie łączyło się już Wcielenia z problemem Odkupienia, lecz podchodzono do niego jako do zagadnienia metafizycznego. Również jedność Boga i człowieka rozpatrywano jedynie w Jezusie Chrystusie, a nie w jej oddziaływaniu na tych, którzy przez wiarę i chrzest są w Chrystusie. Dlatego też nie były te rozważania owocne dla pytania o człowieka, o jego byt i przeznaczenie. Hans Urs von Balthasar uważa, że: „Wszystkie te spekulacje o oddzieleniu pojęcia osoby od pojęcia duchowego podmiotu nie opłacają się, jeśli chodzi o teologiczne określenie bycia osobą Chrystusa i następnie teologiczne określenie innych osób będących w Chrystusie" ${ }^{50}$. Gdy chodzi o przybliżone opisy cech duchowego podmiotu, osoby w zakresie gatunku człowiek, to podmiot może być - w swojej jednorazowości określony i oznaczony — tak uważa Balthasar — jedynie od strony Boga.

53 Por. Grillm ei e r, Jesus, S. 466.

54 Por. Grillme i e r, Jesus der Christus, s. 479.

55 Por. A. N. S. B o ethius, Liber de persona et duabus naturis 3: PL 64, 1313 ; W. Kasper, Jesus, s. 285 n.; H. Urs von B a 1 th a s a r, Theodramatik $2 / 2$, s. $1919 \mathrm{nn}$.

${ }_{58}$ Hans Urs von B thas a r, Theodramatik 2/2, Einsiedeln 1978, s. 202. 
Może pytanie o ludzki byt Jezusa i ludzki byt ludzi w Chrystusie i przez Chrystusa daje się łatwiej rozwiązać od strony pytania: kim jest ten człowiek Jezus Chrystus, z jakiego środka On żyje?

\section{CZŁOWIECZEŃSTWO CHRYSTUSA - CZEOWIECZEŃSTWO CZ£OWIEKA}

\section{Pytania teologii}

Usiłowania zrozumienia czym jest człowiek od strony doświadczenia i myślenia człowieka i wychodzące $\mathrm{z}$ tego pojęcia zrozumienie człowieczeństwa Jezusa Chrystusa i Jego Jedności w Synu Bożym prowadzą do nierozwiązalnych trudności. Na ludzką postać Chrystusa, jaka nas spotyka w świadectwach Pisma, nakłada się uprzednio sporządzony obraz człowieka. Człowieczeństwo Jezusowe wykłada się w kierunku uzyskanego z doświadczenia i myślenia wyobrażenia o człowieku, które się stara więcej lub mniej uzgodnić i pogodzić z Boskością Chrystusa. Dawniej wysuwano mocno Boskość Chrystusa, na Jego człowieczeństwo patrzono od strony Jego Boskości. Wspaniałość Syna Bożego promieniowała poza granice i warunki Jego człowieczeństwa. Obecnie istnieje raczej niebezpieczeństwo zagrożenia boskiego bytu Jezusa Chrystusa ze względu na Jego ludzki byt. Jako osoba został człowiek rozpoznany w chrystologicznych tradycjach o Chrystusie i w chrystologicznych pytaniach. W oparciu o nowe rozumienie człowieka teologowie zapytują o ludzką osobę i o ludzki podmiot w Chrystusie. Z drugiej strony, wychodząc z racjonalistycznego obrazu Boga, natrafiamy na trudność uwikłania Boga lub Syna Bożego $\mathrm{w}$ wydarzenia Krzyża. W oparciu o pojęcie człowieka uzyskane $z$ historii chrześcijaństwa, które rozpoznało człowieka jako osobę, i z doświadczenia, kładzie się nacisk na osobowy samostan człowieka w Chrystusie. Człowiek Jezus Chrystus, w którym Bóg w jakiś sposób działa, jest rozumiany jako działająca osoba lub działający podmiot. Takie wyobrażenie jak to jeszcze wykażemy - nie jest zgodne z przekazem biblijnym. Rozumienie człowieka uzyskane $\mathrm{z}$ historii i doświadczenia człowieka, które pragnie określić człowieka na podstawie człowieka, nie może po prostu opisać ludzkiego bytu Jezusa Chrystusa. Albo trzeba to rozumienie z jednej strony rozszerzyć a $\mathrm{z}$ drugiej ograniczyć, albo nie będzie ono adekwatne do rzeczywistości Jezusa Chrystusa. Ludzki byt Jezusa Chrystusa jest po części tak usamodzielniony, że Syn Boży lub Bóg jest w tym człowieku obecny jedynie jakoby siła. Wynika z tego, że teologia nie może człowieka określić i pojąć tylko od strony człowieka. W świetle wiary przeznaczenie człowieka nie leży po prostu w człowieku. To doświadcze- 
nie czerpane $\mathrm{z}$ historii każe teologom odczytać w Chrystusie, czym jest człowiek. Jeśli się jednak odczyta ludzkie bycie tylko i jedynie na postaci Chrystusa, to taki obraz człowieka nie będzie się zgadzał z człowiekiem, który żyje tu w historii. Człowiek, którym my jesteśmy, nie jest Synem Bożym, nie żyje i nie działa w takiej bezpośredniości z Bogiem jak Jezus Chrystus. Jemu obecność Ducha dana jest w inny sposób niż Jezusowi Chrystusowi. Czym jest człowiek, o tym jakie jest jego przeznaczenie można się więc dowiedzieć jedynie w spotkaniu naszej wiary w człowieka Jezusa Chrystusa z naszym doświadczeniem człowieczeństwa. Jako teologowie musimy się więc starać o spotkanie tego, co uznajemy za urzeczywistnienie człowieka w historii w postaci Jezusa Chrystusa $\mathrm{i}$ w naszym poznaniu $\mathrm{z}$ doświadczenia człowieka $\mathrm{z}$ sobą samym $\mathrm{w}$ historii tego doświadczenia. W przyznaniu się do Jezusa Chrystusa jako prawdziwego człowieka i prawdziwego Boga chodzi więc zawsze o zagadnienie człowieka i przeznaczenie człowieka.

\section{Jezus Chrystus człowiek}

Pisma Nowego Testamentu świadczą o Jezusie Chrystusie jako prawdziwym człowieku. W. Kasper stwierdza: „Fakt, że Jezus z Nazaretu był prawdziwym człowiekiem jest dla Nowego Testamentu zrozumiałym przez się założeniem" ${ }^{57}$.

Tradycja Ewangelii - Ewangeliści opisują Jezusa naprzód jako człowieka. Urodzony przez kobietę, doświadcza potrzeb życia codziennego. Jest głodny (Mt 4, 2; Łk 4, 2), jest zmęczony i prosi „Daj mi pić” ( $\mathrm{J}$ 4, $7)$ i odczuwa pragnienie ( $J 19,28)$. Ulega wzruszeniom duszy i serca oraz nie wstydzi się tego okazać. Płacze nad miastem Jerozolimą (Łk 19, 41) i nad swoim przyjacielem Eazarzem $(J 11,35)$ i wpada w gniew na milczenie faryzeuszy i martwi Go ich upór ( $\mathrm{Mk} 3,5)$. Wodzą Go na pokuszenie ( $M k$ 1, 13; 1-11; Łk 4, 1-13; Hbr 4, 16). Jest posłuszny swoim rodzicom Maryi i Józefowi. Wzrastał i Jego mądrość wzrastała i znajdował upodobanie $u$ Boga i ludzi ( $€ k$ 2, 52). Nie zna godziny swego powrotu (Mk 13, 32; Mt 24, 36). W obliczu swojej gwałtownej śmierci drży i lęk go ogarnia (Mk 13, 33). Modli się do Ojca (Mk 6, 46; Mt 14, 23; Mk 14, 35; Mt 25, 39; Łk 22, 41) i umiera $(15,34)$.

Swiadectwo Gminy - Pozostałe teksty Nowego Testamentu znają Go i opisują jako człowieka. Kuszono Go, tak jak nas kuszono i może On współczuć naszej słabości (Hbr 4, 15). Cierpienie nauczyło Go posłuszeń- 
stwa (Hbr 5, 8). Był on: „posłusznym aż do śmierci, do śmierci na krzy$\dot{z} u^{\prime \prime}$ (Fil 2, 8).

Człowiek Jezus określony przez wole Boża - Żyje On jako człowiek Bogiem i Jego wolą. Od początku jest On w tym, co jest Jego Ojca (飞k 2, 49). Nie przyszedł On, aby rozwiązać Prawo, lecz by je wypełnić (Mt 5, 17). W swojej modlitwie prosi On o spełnienie się woli Bożej (Mt 6, 10). Swoich uczniów wzywa do spełnienia woli Bożej (Mt 12, 50). Kto czyni Wolę Bożą jest Mu bratem i siostrą (Mk 3, 35). Jego pożywieniem jest czynienie woli Tego, który Go posłał i wypełnienie jego dzieła ( $\mathrm{J} 4$, 34). Nie szuka On woli swojej, lecz woli Tego, kto Go posłał (J, 5, 30; $6,38 ; 39,40)$. W obliczu czekającej Go śmierci, gdy „dusza Jego jest smutna aż do śmierci", lęka się i drży i oddaje się woli Ojca (Mk 14, $33-36 \mathrm{pp} ; \mathrm{J} 12,27)$. Jezus jest określony w swoim życiu przez wole Ojca. Jego ludzkie bytowanie jest skierowane na Boga, jest określone przez Boga.

Życie w zaufaniu do Ojca - Jezus Chrystus żyje poza tym w ufności do Ojca. Nawet Jego przeciwnicy to potwierdzają (Mt 27, 45). Jego życie znajduje środek, znajduje siebie $w$ zawierzeniu Ojcu. Nie szuka On siebie, lecz Boga i znajduje siebie w zawierzeniu i posłuszeństwie wobec Boga.

Zyycie wobec Ojca $i$ z Ojca - Do tego Ojca przemawia On mową dziecka i nazywa Go Abba (Mk 14, 36). Skierowany jest bezpośrednio na Niego. Tak, zna On Ojca i Ojciec zna Jego (Mt 11, 27; Łk 10, 21 f).Uważa się za wysłanego przez Ojca. Kto przyjmuje dziecko, przyjmuje Jego, przyjmuje Tego, który Go posłał (Mk 9, 36; Mt 9, 48; J 13, 16. 20; 10, 16). Został, aby zwiastować Królestwo Boże (Łk 4, 43). Uważa siebie za wysłanego na ostatek Syna Bożego (Mk 12, 6 pp). Przybył i wyszedł, aby głosić Królestwo Boże (Mk 1,38). Jego całe ludzkie bycie jest ,tak nieograniczenie wyciśnięte przez Jego przepowiadanie Królestwa Bożego", „,że można Jego ludzkie bycie właśnie przez nie zdefiniować” ${ }^{58}$. Jego ludzkie życie jest określone przez przepowiadanie nadchodzącego Królestwa Bożego; w Nim podarowuje Bóg ludziom na nowy soosób swoją wspólnotę. Wie, że jego posłaniem jest przyniesienie ludzkości tej wspólnoty. Widzi swoje posłanie do zagubionych owiec Izraela (Mt 15, 24). Ponieważ Państwo Boże nie ogranicza się do Izraela, Jego posłannictwo nie może się też ograniczyć do Izraela. Posłano Go i przyszedł nie po to, by $\mathrm{Mu}$ służono, lecz „by służyć i oddać swoje życie jako okup za wielu” (Mk 10, 45).

Bytowanie dla ludzi - Posłuszny woli swego Ojca, jest On dla ludzi. Ufając Ojcu, pozbawiony własnych potrzeb, jest On dla ludzi, których

58 E. Jüng e 1, Gott als Geheimnis der Welt, Tübingen 1977, s. 483. 
spotyka i oddaje życie za wielu (Mk 14, 22 f pp). Jego życie, Jego człowieczeństwo jest wypełnianiem swego posłannictwa, woli Ojca. Wola Ojca, Jego posłaniem jest oddać życie za wielu. Człowieczeństwo Jezusa i Jego życie jest oddaniem woli Ojca za ludzi.

Doświadczenia słuchaczy - Zebrany tłum, który słyszy słowa Jezusa, który doświadcza Go w Jego człowieczeństwie, pyta zdumiony: „Co to jest?" (Mk 1, 17). Ludzie zauważają, że tu głosi się nową naukę z mocą. Uczniom nasuwa się pytanie: „Kim On jest” (Mk 4, 41). Nie można tu przedstawić szczegółowo, jak Jezus - prawie bezpośrednio - odpowiadal na to pytanie swoim rozszczeniem, swoim zachowaniem, swoim nauczaniem z mocą i przezornymi aluzjami. W Jego życiu z posłania rozbrzmiewa roszczenie, które nie może pochodzić od żadnego ludzkiego Ja.

Wyznanie gminy - Odpowiedź wiary gminy chrześcijańskiej może się na tę pośrednią odpowiedź Jezusa powołać. Wiara odpowiada na to pytanie, kim On jest, jednoznacznie wyznaniem Go jako Syna Bożego. Syn Boży musi pozostać w tym, co jest Jego Ojca. Jest On synem ukochanym, który daje się ochrzcić Jano Chrzcicielowi. Jest Synem pochodzącym od Ojca, zwiastującym Królestwo Boże, zwracającym się do ludzi. Marek wkłada wyznanie wiary w usta setnika pod krzyżem. „Gdy setnik stojący na przeciwko Jezusa zobaczył Go umierającego w ten sposób powiedział: „Zaprawdę ten człowiek był Synem Bożym” (Mk 15, 39). Paweł wyznaje w Jezusie Chrystusie Syna Bożego posłanego przez Ojca (Gal 4, 4; Rz 8, 3 n.). Na krzyżu Syn Boży oddaje się ( $R z 15,7,32$ n.). Paweł może powiedzieć, że Bóg posłał Syna swojego w postaci cielesnej, „znajdującej się pod władzą grzechu” (Rz 8, 3; por. 2 Kor 5, 21; Gal 3, 10). Pisma Janowe widzą jednoznacznie w Jezusie Syna Bożego. Wyznania wiary wymieniają Syna Bożego jako tego, który stał się człowiekiem, urodził się z dziewicy, cierpiał i umarł.

Kto chce przejąc świadectwa Pisma i wyznanie Kościoła, musi powiedzieć, że Syn Boży cierpiał i umarł za nas. Dlatego musimy za Hansem Ursem von Balthasarem utrzymywać, że „Wcielonemu Logosowi nie można przypisywać podwójnej świadomości". Posłannictwo, którego Jezus jest świadomy, jest posłaniem jedynego Syna. Wie On, że jako człowiek czyni swobodnie to, co Logos chce czynić, lub też - co wychodzi na to samo - człowiek Jezus wie, że to, co czyni w wolności, jest czynem Syna Bożego. Nie wykonuje tego, co inny ktoś zlecił do zrobienia" ${ }^{59}$. Odpowiedź na pytanie uczniów: „Kim On jest?” brzmi według świadectwa Nowego Testamentu jednoznacznie: Synem Bożym.

59 Hans Urs von Balthas ar, Theodramatik 2/2, s. 208. Balthasar odsyla do odnośnych teksitów Grzegorza z Nazjanzu i do Dwuna'stu anatematy'zmów Cyryla (DS 262+4011). 
Przyjmując to, co uprzednio powiedziano, można się odważyć na stwierdzenie: Syn Boży przeżywa swój byt człowieczy, spełniając w historii posłanie Ojca i posłuszny Ojcu - tu nie można po prostu powiedzieć Bogu - wypełniając wolę Ojca w swoim historycznym życiu służy ludziom i umierając oddaje się za ludzi. Działalność Syna Bożego w historii dowodzi siebie ,,jako miejsce objawienia tego, co ludzkie a nawet ludzkiego samobycia" " ${ }^{00}$. Syn rozwija działalność ludzką i doprowadza do swojej pełnej i niezbywalnej samodzielności i godności. To spełnianie posłannictwa i urzeczywistnienie bytu człowieczego przebiega w czasie i historii. Ale jest to Syn Boży, a nie po prostu człowiek doskonały, który jako człowiek tę ludzką historię życia kształtuje i wykonuje. Dokonuje tego życia, przychodząc z przeszłości i zdążając ku przyszłości, która nie jest Mu znana jasno we wszystkich szczegółach Jego posłania. Jego przyszłość otwiera się przed Nim na pewno z jednej strony: ze strony Jego posłania, Jego stosunku do Ojca, ale też na pewno z procesów historii, w której Jego życie się rozgrywa. Nie przewidując jeszcze końca, wypełnia Swoje posłannictwo w ufności do Ojca ${ }^{61}$. Nie ma On też w Swoim ludzkim byciu podczas swego życia w czasie i historii całości swego polecenia stale przed oczyma. On też urzeczywistnia to posłanie w sposób historyczny. Podejmuje wymagania, które Mu stawia w danej chwili Jego otoczenie, Jego ufność w Ojcu. Jego istnienie dla ludzi dokonuje się w życiu w spotkaniach, które przemijają i przynoszą doświadczenia dla dalszych wymagań w przyszłości. Także posłuszeństwo sięgające w ostateczność i sięgająca poza historię ofiara na krzyżu jest dokonaniem Syna Bożego w Jego człowieczym bycie. Tutaj też działa nie człowiek doskonały, tylko Syn Boży. To, co się dzieje na krzyżu, nie jest jedynie sprawą między Bogiem a człowiekiem, lecz między Ojcem i Synem ${ }^{62}$. Ponieważ Syn Boży wykonuje swoje posłanie jako człowiek w historii, kieruje Nim w spełnianiu Jego zadania Duch ${ }^{63}$.

Jezus człowiek - ludzie

Jeśli więc chcemy odczytać prawdziwe człowieczeństwo człowieka z postaci i historii Jezusa Chrystusa, to musimy zauważyć, że Chrystus kształtuje swoje człowieczeństwo jako Syn Boży. Ponieważ występuje

${ }^{60}$ P. Hün ermann, Gottes Sohn (przypis 27), s. 1211. Być może trzeba rozumieć to bardziej od strony Syna niż od strony wzajemnego przenikania ludzkiiej energeia i boskiej dynamis.

${ }_{61}$ Por. B a lt th a s a r, Theodramatik 2/2, s. 156 n. Ujęcia Hünermanna i Wiederkehra nadają się w pełni do dalszego rozwinięcia w kierunku myśli Baltha'sara. 337.

${ }_{62}$ P.or. H. Urs von Balthas ar, Theodramatik 3, Einsiedeln 1380 , s. $295-$

${ }^{03}$ Por. W. Ka s'per, Jesus der Christus, 3. $296 \mathrm{nn}$; B a 1 th a sar, Theodramatik 2/2, s. $167-175$. 
z mocą, odsuwa na bok święte tradycje Izraela, nazywa Boga swoim Ojcem, widzi siebie jako Umiłowanego Syna (Mk 12, 1-12 par.: przypowieść o złych pracownikach winnicy), dlatego musi znać swoje posłannictwo i swój byt. Nie wypowiadamy się, czy mamy prawo próbować napisać psychologię, czy też historię samoświadomości Jezusa. Dla naszego pytania o człowieczeństwo człowieka ważne jest widzieć, że człowiek Jezus Chrystus jest otwarty na Boga i z Bogiem związany również w swym historycznym życiu w całkiem inny sposób niż możemy my być kiedykolwiek w naszym życiu jako ludzie, jako obdarzeni Łaską i jako zbawieni. To innego rodzaju bycie jednym ludzkiej natury Jezusa z Bogiem, bycie człowieka Jezusa w Synu wyraża się w ludzkiej wiedzy i ludzkiej wolności Jezusa. Istnieje w Nim też niewiedza, można Go kusić, ale On w inny sposób może zdobyć wiedzę i jest w swojej wolności wolnym w stosunku do Boga. Syn Boży stał się człowiekiem i równym nam z wyjątkiem grzechu, a nawet dźwigał grzechy człowieka. Lecz nie żył z ranami i bliznami, które nam zadał grzech.

\section{Czlowiek przed Bogiem}

Określenie człowieka od strony Boga - Jeśli zapytamy, wychodząc od Jezusa Chrystusa, o prawdziwe człowieczeństwo człowieka, musimy te różnice brać pod uwagę. Ale wychodząc od Jezusa Chrystusa okazuje się, że nie da się określić człowieczeństwa od strony człowieka i nie wypełnia się ono w „humanitarności, wolności, życiu, miłości, pokoju” i w przezwyciężaniu nieprawości, zła, tego co niepiękne i nieludzkie ${ }^{64}$. Od Chrystusa wychodząc, okazuje się, że człowieczeństwo otrzymuje sens i przeznaczenie od strony Boga. Człowiek jest jedynie wtedy prawdziwy, jeśli skierowany jest do Boga. Jeśli dokonuje swojego żywota historycznego w tym skierowaniu do Boga, będzie też żył dla innych, będzie się mógł tym innym oddać w ufności do tego Boga. Człowieczeństwo dokonuje się prawdziwie po ludzku w historii w spojrzeniu na wolę Bożą, w bytowaniu i oddaniu dla innych. Od strony Chrystusa okazuje się również, że ludzkie bytowanie wskazuje poza historię w świat pozagrobowy. Chrystus dokonuje swojego posłania życiowego w sensie powrotu do Ojca. Celem i przeznaczeniem życia człowieczego jest Bóg i prawdziwa wspólnota z Bogiem. Swoją doskonałość odnajduje człowiek w Bogu, w tym leży jego nieporównywalna godność. Ponieważ Bóg jest jego przeznaczeniem, nie może go wiązać to, co zostało stworzone, nie może on służyć wewnątrzświatowym celom. To przeznaczenie od Boga pochodzące i do Boga skierowane ma człowiek w swojej wolności przejąć. W tej wol-

${ }^{64}$ H. K üng, Christsein, s. 594 . 
ności jest on nietykalny. Nie wolno mu jej nawet $\mathrm{w}$ imię przeznaczenia ograniczać lub odbierać.

Bytowanie dla innych - Wychodząc od Chrystusa okazuje się również, że człowieczeństwo oznacza nie tylko być ze sobą razem, ale również być dla drugiego. Życie ludzkie uzyskuje człowieczeństwo w bytowaniu dla innych i w oddaniu. To oddanie może popaść pod znak krzyża.

Człowiek $w$ historii - Swoje przeznaczenie może człowiek $\mathrm{w}$ historii przyjąc jedynie w historycznym działaniu. Posłuszeństwo wobec Boga urzeczywistnia on przede wszystkim w swoim zachowaniu się wobec innych ludzi, którzy go spotykają. Przeznaczenie dla Boga człowiek tego czasu dokonuje poprzez działanie $w$ historii. Nigdy nie rozpoznaje on w niej tego przeznaczenia w całości. Posiada je tylko wycinkowo i niejasno. Jest to ważne także dla ludzi, którzy w odpowiedzialności za innych ukazują kierunki i wytyczają drogi. W ten sposób człowiek, zdany na niebezpieczeństwo błądzenia, przy całej odpowiedzialnej przezorności, może urzeczywistnić to przeznaczenie jedynie w ufności do Boga w poszczególnych krokach życia. $\mathrm{Ku}$ innym pozostaje on zdany na ufność, ponieważ nie poznaje $w$ pełni skutków swego działania i swoich decyzji. Wiara widzi przeznaczenie człowieka w tym Bogu, który powołuje nas jako Ojciec, Syn i Duch do wspólnoty ze Sobą.

Te rozważania powinny być jeszcze rozszerzone przez zetknięcie ujęcia człowieka odczytanego w Jezusie z doświadczeniami, jakie człowiek przeprowadza na sobie, z myślą człowieka o sobie ${ }^{65}$. W uzupełnieniu należałoby $\mathrm{w}$ dalszym ciągu jeszcze badać problem egzystencji Chrystusa i egzystencji człowieka na podstawie zachowania. Jezus Chrystus jako Człowiek jest Osobą, która jest Osobą Syna Bożego. Toteż, punktem odniesienia w naturze ludzkiej Chrystusa jest to, że On jest Synem Bożym, czyli drugą Osobą Boską. Człowiek bierze swoją ludzką naturę nie od siebie, ale od Boga na podstawie wezwania (Anruf) Bożego. Toteż, ostatecznie człowiek staje się osobą $\mathrm{w}$ wyniku stwórczego wezwania przez Boga do szczególnego współżycia z Nim.

Przeskład: Ks. Henryk Piszkalski

65 Por. W. Ka sper, Christologie und Anthropologie: ThQ 162 (1982), s. 202221. 